\title{
UNMANNED AERIAL VEHICHLE WING FUSELAGE JUNCTION OPTIMALISATION WITH FINITE ELEMENT METHOD
}

\author{
Máté KONDOR, ${ }^{1}$ Gergely DEZSŐ ${ }^{2}$ \\ University of Nyíregyháza, Department of Physics and Production Engineering, Nyíregyháza, Hungary \\ ${ }^{1}$ kmatehun55@gmail.com \\ ${ }^{2}$ dezso.gergely@nye.hu
}

\begin{abstract}
Nowadays one of the main lines of development in aerial craft is the design and construction of unmanned aerial vehicles (UAV's). Within this wide topic, development of ultralight (UL) aircrafts is especially popular because of their versatility and relative low cost. My task was to design the shape of an airplane wing-fuselage junction, which will be classified as an ultralight and unmanned aerial vehicle. The most optimal wing-fuselage junction is made with the Ansys sim-ulating program, including model calculations. Based on the calculations and results, solutions can be recommended. With CAD geometry models, first stage of testing of the aircraft with 3D printed models, is prepared.
\end{abstract}

Keywords: wing-fuselage junction, finite element method, unmanned aerial vehichle, ultralight, simulation.

\section{Introduction}

These days - along with the „traditional” onboard, pilot controlled airplanes and helicopters - many aircraft and tools have appeared, which are able to fly without an on-board pilot, being remotely or self-controlled. Fixed wing aircraft and helicopters - without on-board pilots - have been developed and used in different variants with maximum take-off masses ranging from a few decagrams to as much as ten tons.

Today there are several types of aircraft that are controlled and driven without human intervention, the use of digital technology enabling them to fly. These aircraft are able to detect their environment, navigate and be controlled by themselves. [1]

This report aims to optimise an aircraft's wing-fuselage junction. The aircraft - which is under development - is to be classified as an „Ultralight” (UL) and „Unmanned Aerial Aircraft” (UAV) - wing-fuselage junction optimisation utilising the Ansys simulation program including model calculations. The cross-section of the fuselage of this airplane is not „traditional” but hexagonal.

Resources concerning wing-fuselage junction, alternate fuselages and wing configurations were studied, including the position of the main planes. Only well-known and well-tested fillets and shapes were used to build up some of the aircraft wing-fuselage junctions. For these variants flow simulation models were set up, then simulation and evaluation was made. Based on the results, suitable wing-fuselage junctions were determined.

For achieving the minimum amount of drag, a suitable wing-fuselage junction should be used, because it can improve the aircraft flying characteristics and lifetime. [2]

A suitable wing-fuselage junction can be achieved by:

- wing configuration including position of the plane;

- use of fairings;

-fillets at the wing-root junction;

- use of extensions (LERX) [2]. 


\subsection{Base information}

$\begin{array}{ll}\text { Mass: } & \sim 450 \mathrm{~kg} \text { (predicted) } \\ \text { Wingspan: } & \sim 10.6 \mathrm{~m} \text { (planned) } \\ \text { Fuselage length: } & 7 \mathrm{~m} \\ \text { V shape: } & 3^{\circ} \\ \text { Cruising speed: } & 40 \mathrm{~m} / \mathrm{s}(144 \mathrm{~km} / \mathrm{h}) \\ \text { Fuselage diameter: } & 1.07 \mathrm{~m}\end{array}$

The chord length at the root of the wing is limited to between $1000 \mathrm{~mm}$ and $1600 \mathrm{~mm}$, because of the geometrical characteristics of wing and fuselage connection.

Junction rounding and shaping (fillet) must fall between $50 \mathrm{~mm}$ and $280 \mathrm{~mm}$ (radius), and this depends on the wing chord length

\section{Analysing the wing-fuselage junction with the finite element method}

The wing-fuselage junction could be analysed using many methods. Nowadays one of the most used and efficient methods (regarding not just the time factor, but the economy factor) is a model simulation using the finite element method.

Simulation usually starts with the so-called preprocessing step.

The first step before simulating the model is to divide the geometry into many small finite parts, which is called mesh or meshing. While creating a new mesh, we should consider its element type, size, desired precision and the solution time. Most programs, which contain simulation with the finite element method, can complete the meshing automatically with default configuration, but manual settings are also available. [3]
There are programs which contain a finite element module, for example: CATIA V5, SolidWorks, Autodesk Inventor, etc.

Better known programs including finite element module: Analysis3D, CalculiX, Nastran and this investigation was completed with the aid of Ansys.

\subsection{Wing-fuselage junction types}

Shaping and forming the junction was based on „Jirapat Supamusdisukul: Experimental Investigation of Wing-Fuselage Integration Geometries Including CFD Analyses” [4] and „Darrol Stinton: The Design of the Aeroplane” [5].

\subsubsection{Optimal position of the wing}

Jirapat Supamusdisukul analysed 5 wing configurations with 8 different pitch angles using finite element method simulation, then he checked if the simulation and the wind tunnel measurements were the same. Based on the results, he advised which wing configuration should be used.

Supamusdisukul began analysing the mid-wing configuration, -which is about half of the fuselage height - then he continued with shoulder wing and high wing.

\subsubsection{One type of the optimal wing-fuselage junction}

Based on „Darron Stinton: The Design of the Aeroplane", the wing-fuselage junction should look like this: around the leading edge wing-fuselage, the radius must be between $5-10 \%$ of the wing chord length, around the trailing edge, this value is $10-20 \%$. We used this information to build up different wing-fuselage junctions.

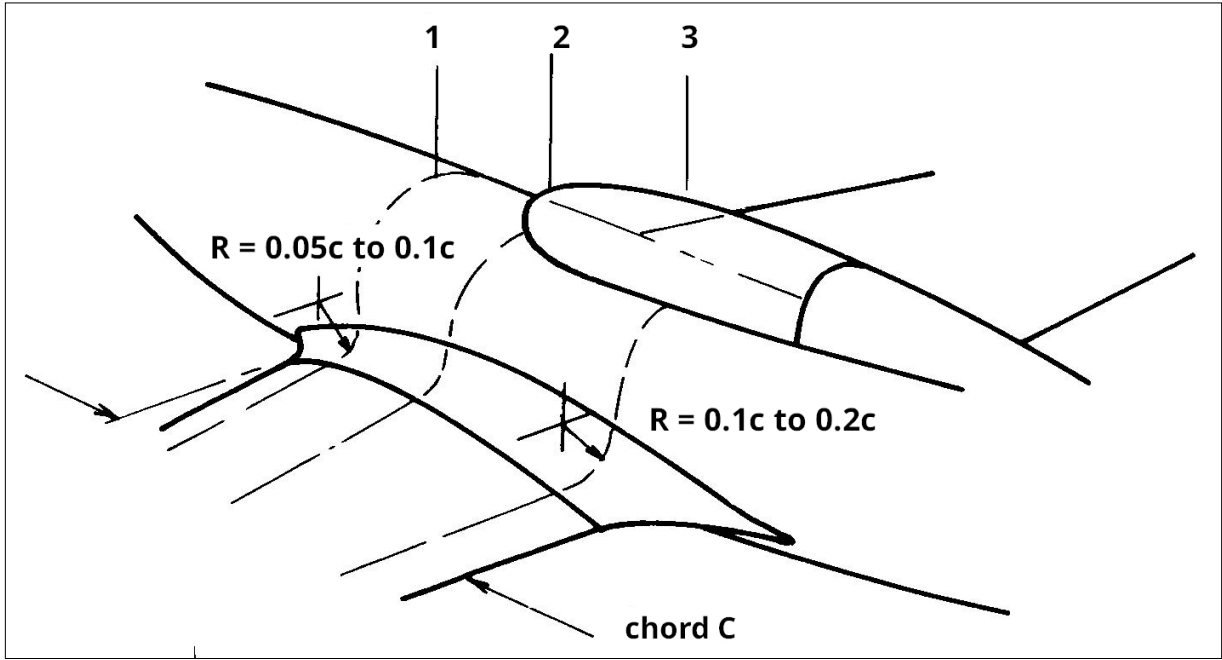

Figure 1. The values of wing-fuselage junction radiuses [5] 
Table 1. Presenting the 2 types

\begin{tabular}{|c|c|}
\hline $1000 \mathrm{~mm}$ & $1400 \mathrm{~mm}$ \\
\hline $0 \mathrm{~mm}$ & $0 \mathrm{~mm}$ \\
\hline $50-100 \mathrm{~mm}$ & $70-140 \mathrm{~mm}$ \\
\hline $100-200 \mathrm{~mm}$ & $140-280 \mathrm{~mm}$ \\
\hline
\end{tabular}

\section{Planning the wing-fuselage junction}

\subsection{Preparations and 3D models}

The first task was to choose the appropriate length of the wing root and wing-fuselage junction radius. The firm - which ordered the work - did not mention any limitation concerning the junction; therefore, using imagination along with the books, 6 3D models were created in SolidWorks. 3 of the models' wing-root lengths are $1000 \mathrm{~mm}$, and 3 of them $1400 \mathrm{~mm}$.

Models were created in Solidworks, and imported into Ansys. In Ansys, the space for the airflow was added. To achieve it, the Solidwork model subtraction is made from a $1,5 \mathrm{~m}$ (width) x $7 \mathrm{~m}$ (length) x $2 \mathrm{~m}$ (height) solid body. This body will be the space where air-flow could be analysed.

The body for the air does not involve the whole airplane - symmetry option is used during simulations, so the same results could be obtained using less elements and less time, because the airflow effects at the wing-tip do not make big difference around the wing-root.

The Figure 2. radiuses from leading edge to trailing edge: $50 \mathrm{~mm}, 60 \mathrm{~mm} ; 70 \mathrm{~mm} ; 80 \mathrm{~mm} ; 90$ $\mathrm{mm} ; 100 \mathrm{~mm}$.

The Figure 3. radiuses from leading edge to trailing edge: $100 \mathrm{~mm}, 120 \mathrm{~mm} ; 140 \mathrm{~mm} ; 160 \mathrm{~mm}$; $180 \mathrm{~mm} ; 200 \mathrm{~mm}$.

The Figure 4. radiuses from leading edge to trailing edge: $70 \mathrm{~mm}, 84 \mathrm{~mm}$; $98 \mathrm{~mm} ; 112 \mathrm{~mm} ; 126 \mathrm{~mm}$; $140 \mathrm{~mm}$.

The Figure 5. radiuses from leading edge to trailing edge: $140 \mathrm{~mm}, 168 \mathrm{~mm} ; 196 \mathrm{~mm} ; 224 \mathrm{~mm}$; $252 \mathrm{~mm} ; 280 \mathrm{~mm}$.

\section{Results}

The results produced with aerodynamic simulations are shown in Table 2. and Table 5. Meshing and simulation data are given in Table 3-4. and 6-7.

Based on the Table 2. results, the $70 \mathrm{~mm}$ fillet junction is the most optimal for the 1400 $\mathrm{mm}$ wing-chord type. A $70 \mathrm{~mm}$ fillet means the

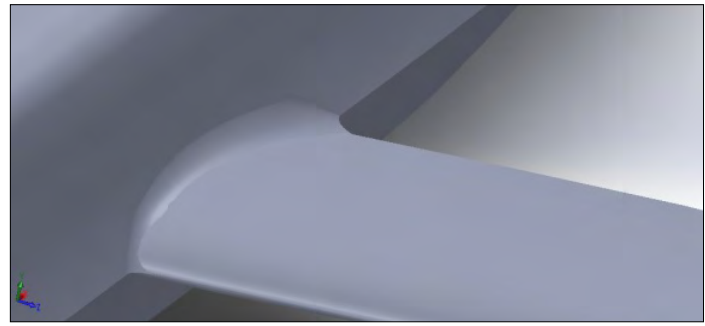

Figure 2. Smaller radius for the $1000 \mathrm{~mm}$ type

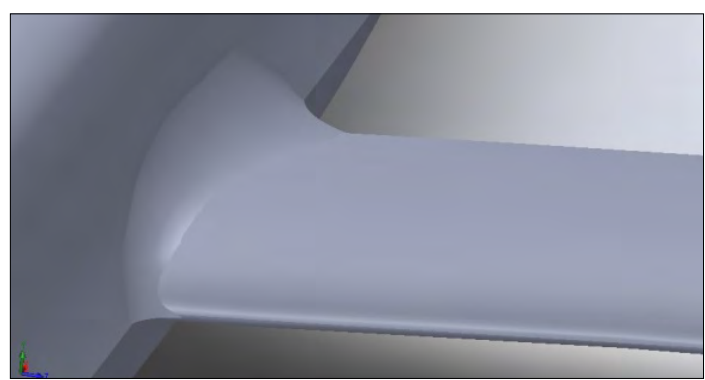

Figure 3. Larger radius for the $1000 \mathrm{~mm}$ type

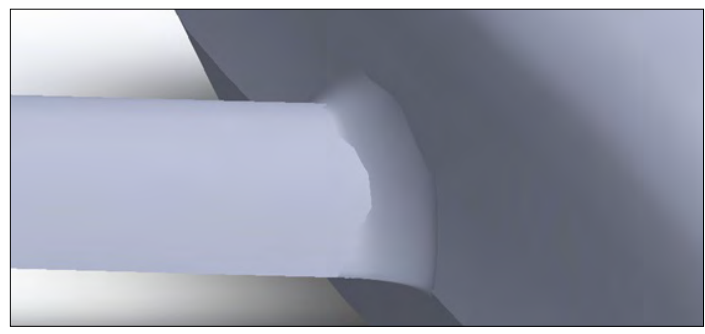

Figure 4. Smaller radius for the $1400 \mathrm{~mm}$ type

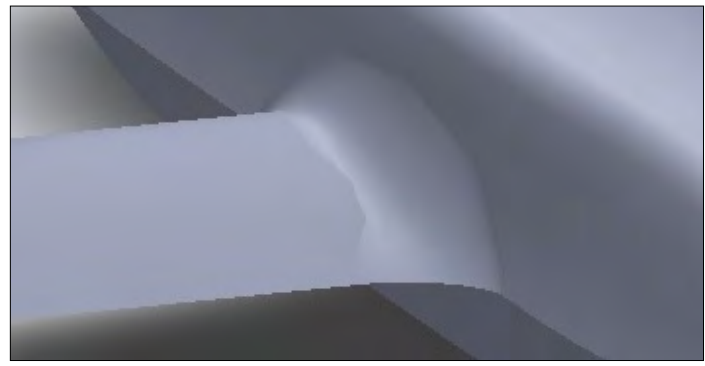

Figure 5. Larger radius for the $1400 \mathrm{~mm}$ type

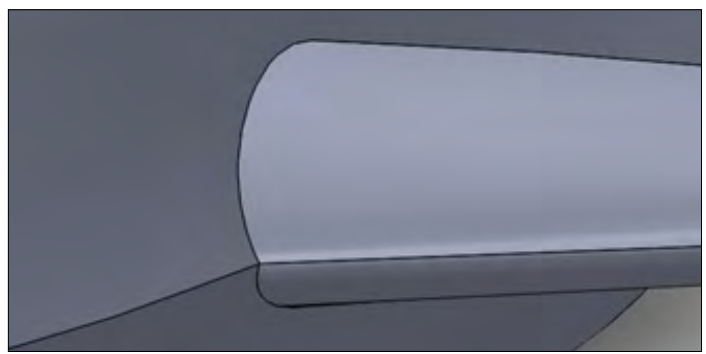

Figure 6. Wing-fuselage junction 
Table 2. The results of the type „1400 $\mathrm{mm}$ ”

\begin{tabular}{|c|c|c|}
\hline Radius [mm] & Lift [N] & Drag [N] \\
\hline no fillet & 240.577 & 16.4413 \\
\hline 70 & 247.447 & 16.5220 \\
\hline 140 & 231.084 & 25.0226 \\
\hline
\end{tabular}

Table 3. Simulation data for the $1400 \mathrm{~mm}$ type

\begin{tabular}{|c|c|c|}
\hline Radius [mm] & $\begin{array}{c}\text { Time elapsed } \\
\text { [s] }\end{array}$ & Iteration \\
\hline- & 1765 & 38 \\
\hline 70 & 2031 & 37 \\
\hline 140 & 1568 & 35 \\
\hline
\end{tabular}

Table 4. Meshing data for the $1400 \mathrm{~mm}$ type

\begin{tabular}{|c|c|c|c|}
\hline Radius [mm] & Elements & Nodes & Faces \\
\hline nincs & 2174615 & 411018 & 189598 \\
\hline 70 & 2249888 & 425435 & 202754 \\
\hline 140 & 2252722 & 425721 & 195940 \\
\hline
\end{tabular}

leading edge shaped radius value of the wing-fuselage junction. Around the trailing edge the value is $140 \mathrm{~mm}$ and between those transient (about $50 \%$ of the chord, the radius is around $105 \mathrm{~mm}$ ).

There are no big differences between the junction with "no fillet” and the „70 mm” type when comparing their "Drag” data, but there is more than $1 \%$ difference for the „70 mm” type at „Lift”, so the latter could be more effective.

Based on the results and the type " $1400 \mathrm{~mm}$ ", the $50 \mathrm{~mm}$ radius is recommended from the 3 types of shape for the $1000 \mathrm{~mm}$ type.

\section{Summary}

Based on the results, We can recommend a radius of $50 \mathrm{~mm}$ or $70 \mathrm{~mm}$ shaped wing-fuselage junction, depending on the final length of the wing-chord and it would be manufactured with 3D printers.
Table 5. The result of the type "1000 mm"

\begin{tabular}{|c|c|c|}
\hline Radius [mm] & Lift [N] & Drag [N] \\
\hline no fillet & 213.026 & 12.2747 \\
\hline 50 & 214.627 & 12.2671 \\
\hline 100 & 208.656 & 11.9574 \\
\hline
\end{tabular}

Table 6. Simulation data for the $1000 \mathrm{~mm}$ type

\begin{tabular}{|c|c|c|}
\hline Radius [mm] & $\begin{array}{c}\text { Time elapsed } \\
\text { [s] }\end{array}$ & Iteration \\
\hline- & 1753 & 37 \\
\hline 50 & 1918 & 38 \\
\hline 100 & 1833 & 38 \\
\hline
\end{tabular}

Table 7. Meshing data for the $1000 \mathrm{~mm}$ type

\begin{tabular}{|c|c|c|c|}
\hline Radius [mm] & Elements & Nodes & Faces \\
\hline- & 2185674 & 412768 & 189068 \\
\hline 50 & 2272646 & 428672 & 194336 \\
\hline 100 & 2274477 & 428686 & 193308 \\
\hline
\end{tabular}

\section{References}

[1] Drónpilóták Országos Egyesülete, Mi az a Drón. (What is drone? accessed on 18. july 2018) https://doe.hu/mi-az-a-dron

[2] Sascha S.: Comparison of design rules regarding the wing-body junction flow of a subsonic aircraft. University of Technology Kosice, I/1. (2011).

[3] Tamás P., Bojtos A., Décsei-Paróczi A., Fekete R. T.: Végeselem módszerek. Hálókészítés. BME MOGI, 2014. (2.3. Hálókészítés)

http://www.mogi.bme.hu/TAMOP/vegeselem_ modszerek/book.html

[4] Jirapat S.: Experimental investigation of wing-fuselage integration geometries including CFD analyses. Computational Fluid Dynamics (CFD) Simulation Results and Discussion. University of Maryland, 2008. 68.

[5] Darrol S.: The Design of the Aeroplane. Arrangement of surfaces. BSP Professional Books. Oxford, 1983. 171. (Fig. 4.24). 